\title{
Pengembangan Metode Pendeteksi Modifikasi Citra Menggunakan Metode Error Level Analysis
}

\author{
I Gede Nengah Bayu Darmawan, Gusti Made Arya Sasmitha, Putu Wira Buana \\ Program Studi Teknologi Informasi, Fakultas Teknik, Universitas Udayana \\ Bukit Jimbaran, Bali, Indonesia Telp. (0361) 701806 \\ e-mail: bayudarmawan134@gmail.com, aryasasmita@it.unud.ac.id, wbhuana@gmail.com
}

\begin{abstract}
Abstrak
Modifikasi citra adalah proses manipulasi pada sebagian atau seluruh daerah citra dengan bantuan teknik pemrosesan citra digital. Pemalsuan citra pada umumnya sulit untuk dianalisa secara kasat mata karena citra hasil dari proses modifikasi citra sulit untuk dibedakan secara kasat mata. Metode Error level analysis (ELA) adalah sebuah metode untuk mendekteksi modifikasi citra dengan menyimpan ulang citra pada level kualitas tertentu, dalam hal ini melakukan kompresi citra dan kemudian melakukan perhitungan terhadap perbedaan pada level kompresi citra. Aplikasi yang dibuat memiliki dua proses utama yaitu filter citra dan analisis nilai Error Level Analysis pada hasil citra filter. Fungsi filter pada aplikasi yang dibuat bertujuan untuk menguji kemampuan metode ELA dalam mendeteksi modifikasi citra dengan cara menganalisis citra hasil proses filter yang dilakukan oleh pengguna aplikasi. Fungsi analisis nilai ELA dilakukan untuk mengetahui jumlah atau nilai persentase nilai ELA pada citra hasil filter, dimana nantinya aplikasi melalui rentan persentase nilai ELA yang didapatkan melalui analisa uji coba yang dilakukan, maka didapatkan rentan nilai persentase sebagai dasar menentukani citra modifikasi dengan menggunakan metode ELA.
\end{abstract}

Kata Kunci: Digital Image Forensic, Modifikasi Citra, Error Level Analysis (ELA), Android

\begin{abstract}
Image modification is the process of manipulation in a part or all of the image area with the help of digital image processing techniques. Image modification is generally difficult to analyze by naked eye because the results of the image modification process are difficult to distinguish by naked eye. Error level analysis (ELA) method is a method for detecting image modification by restoring the image at a certain quality level, in this case compressing the image and then calculating the difference in the image compression level. The application created has two main processes, namely the image filter and analysis of the Error Level Analysis value on the filter image results. The filter function in the application created aims to test the ability of the ELA method in detecting image modification by analyzing the results of the filter process carried out by the application user. The ELA value analysis function is carried out to determine the number or percentage value of ELA values in the filtered image, where later by susceptible to the percentage of ELA values through the experiments carried out, the percentage value is susceptible to determine the modified image using the ELA method.
\end{abstract}

Keywords: Digital Image Forensic, Modified Image, Error Level Analysis (ELA), Android

\section{Pendahuluan}

Pemalsuan citra sering tak dapat dikenali secara kasat mata karena citra hasil modifikasi sulit ditentukan keasliannya. Kasus modifikasi citra yang terjadi misalnya adalah kasus beredarnya foto-foto yang melibatkan pejabat, artis atau publik figur yang memuat konten-konten yang sensitif sehingga menimbulkan kehebohan di masyarakat. Kemunculan citra-citra digital yang dimodifikasi akan menimbulkan permasalahan-permasalahan dalam kehidupan sosial seperti penyebaran informasi-informasi yang tidak benar, sehingga sangat mudah terjadi kesalah pahaman. JPEG "Joint Photographic Experts Group" merupakan salah satu format citra yang paling sering digunakan, dimana JPEG adalah sebuah format citra yang memiliki format lossy (dimana metode untuk mengkompresi data dengan hasil perbedaan data yang tidak terlalu jauh dari data sebelum kompresi), tetapi banyaknya error yang tesimpan tidak sama dengan citra 
sebelum proses kompresi. Metode Error level analysis (ELA) adalah sebuah teknik untuk mendekteksi manipulasi citra dengan menyimpan ulang citra pada level kualitas tertentu, dan kemudian menkomputasi perbedaan antara citra kompresi dan citra sebelumnya. Jika citra tidak diubah, grid $8 \times 8$ piksel seharusnya memiliki potensi error yang sama. Tetapi, jika citra diubah, sebagian dari citra yang telah dimanipulasi akan memiliki potensi error yang lebih tinggi dari bagian citra lainnya. ELA bekerja dengan menyimpan ulang citra untuk mengetahui rata-rata nilai error [2].

Penelitian [3] menjelaskan tentang metode baru untuk deteksi citra palsu yang dihasilkan dari teknik copy-move. Teknik copy-move merupakan salah satu teknik pemalsuan citra dengan cara mengambil objek tertentu dari citra asli dan menambahkannya pada citra tersebut dengan tujuan untuk menambah jumlah atau merubah objek yang sama pada citra asli. Penelitian ini bertujuan untuk mendeteksi citra palsu yang dihasilkan oleh teknik copy-move dan citra palsu copy-move yang telah dimodifikasi dengan operasi rotasi dan ekualisasi histogram. Fitur deteksi yang digunakan adalah Ordinal Measure dari koefisien Discrete Cosine Transform (OM-DCT).

Penelitian [4] membahas Pemalsuan citra dengan maksud menutupi sebagian objek pada citra dengan blok lain pada citra yang sama disebut dengan copy-move. Deteksi copy-move pada citra dapat dilakukan pada domain spasial melalui pengolahan pada tiap pikselnya maupun pada domain frekeunsi melalui beberapa fungsi transformasi. Penelitian ini mengusulkan deteksi copy-move pada domain spasial dengan mengembangkan Metode Block Macthing. Metode yang diusulkan terbagi atas dua pendekatan yaitu excact match dan robust match.

Artikel [5] memperkenalkan analisis error pada JPEG untuk mempelajari forensik citra. Melalui analisis berbagai nilai error pada citra JPEG yang dikompresi dan hubungan mereka dalam format JPEG kompresi ganda, makalah ini telah mengembangkan tiga analisis forensik skema. Sebuah fitur 1-D yang sederhana dan sangat efektif berhasil diperkenalkan untuk mengidentifikasi apakah gambar bitmap yang diberikan memiliki sebelumnya telah dikompresi JPEG. Setelah bitmap diidentifikasi sebagai gambar JPEG, makalah ini telah mengembangkan teknik untuk lebih jauh memperkirakan langkah-langkah kuantisasi dan mendeteksi kuantisasi tabel yang digunakan untuk citra JPEG. Makalah ini menunjukkan bahwa metode baru yang bekerja secara efektif dan secara signifikan mengungguli teknik yang ada dalam literatur.

Penelitian [6] dibangun dengan menggunakan teknologi penyimpanan pada server (MySQL) dan juga menggunakan Meode Eigenface. Tingkat keberhasilan dariuji coba identifikasi wajah sebesar $68 \%$ dan tingkat salah pengenalan sebesar $32 \%$, dari total uji coba sebanyak 25 kali identifikasi. Beberapa faktor penting yang mempengaruhi tingkat keberhasilan identifikasi yaitu posisi wajah dan intensitas cahaya saat melakukan pendaftaran.

Penelitian [7] membahas mengenai pengenalan Resistor, dengan memanfaatkan teknologi pengolahan citra digital yaitu metode HSV (Hue Saturation Value). HSV berguna sebagai batas warna yang menjadi acuan dari gelang warna Resistor, dengan menerapkan metode iniaplikasidapat melakukan pengenalan terhadap Resistor yang diinputkan, untuk kemudian memberikan informasi yang berkaitan dengan tipe dan nilai Resistor. Penelitian ini memiliki presentasekeberhasilan dalam pengenalan nilai dan tipe Resistor sebesar $57 \%$ untuk salah dikenali $30 \%$ dan tidak dikenali sebesar $13 \%$.

Penelitian-penelitian sebelumnya yang telah dijelaskan tersebut merupakan dasar dari penelitian ini dalam membahas mengenai perancangan dan pembuatan aplikasi pengolahan citra untuk mendeteksi modifikasi citra dengan menggunakan metode Error Level Analysis berbasis andorid. Aplikasi yang dibuat memiliki dua proses utama yaitu filter citra dan analisis nilai Error Level Analysis pada hasil citra filter. Fungsi filter pada aplikasi yang dibuat dengan tujuan untuk menguji kemampuan metode Error Level Analysis (ELA) dalam mendeteksi modifikasi citra dengan cara menganalisis citra hasil proses filter yang dilakukan oleh pengguna aplikasi. Fungsi analisis nilai Error Level Analysis (ELA) dilakukan untuk mengetahui jumlah atau nilai persentase nilai Error Level Analysis (ELA) pada citra hasil filter, dimana nantinya dengan mengalasis rentan persentase nilai Error Level Analysis (ELA) melalui uji coba yang dilakukan, diharapkan dalam pengembangan aplikasi berikutnya, aplikasi dapat medeteksi citra modifikasi secara langsung serta memberikan informasi ke pengguna tanpa perlu pengguna melakukan analisis secara manual terhadap citra hasil filer oleh metode Error Level Analysis (ELA).

\section{Metodologi Penelitian}


Metodologi Penelitian dengan menggunakan aplikasi android yang dirancang dengan menerapkan metode Error Level Analysis menggunakan data uji [8]. Pengujian dilakukan dengan 2 tahap yaitu, pengujian terhadap filter citra hasil metode dan menguji nilai error pada filter citra untuk menentukan kemampuan metode Error Level Analysis dalam mendeteksi citra modifikasi.

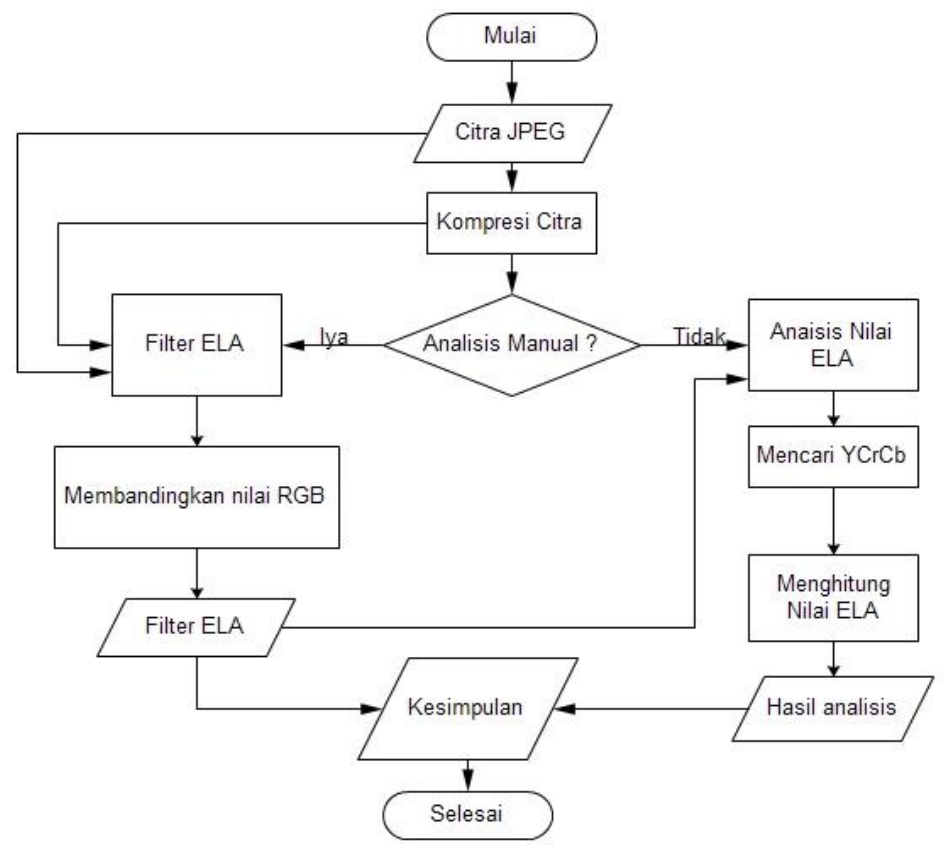

Gambar 1. Flowchart Gambaran Umum Sistem

Aplikasi Pengolahan Citra Pendeteksi Modifikasi Citra Menggunakan Metode Error Level Analysis Berbasis Android, citra yang dinnputkan akan melauli proses kompresi terlebih dahulu. Proses berikutnya nilai RGB tiap piksel dari citra awal dan nilai RGB dari citra kompresi akan dihitung selisihnya yang kemudian akan menjadi sebuah citra baru yaitu citra ELA.

Rancangan Perhitungan Fungsi Analisis Nilai Error Level Analysis melalui beberapa tahapan proses untuk mencari nilai error pada citra yang dilakukan pada tiap grid $8 \times 8$ piksel menggunakan kernel $8 \times 8$ pada citra yang telah mengalami kompresi.

\subsection{Tahap Konversi Nilai RGB ke YCrCb (Luminance dan Crominance)}

Tahap pertama pada proses analisis nilai Error Level Analysis dengan menentukan nilai Luminance dan Crominance pada Kernel 8x8 Citra Kompresi. diambil dari [9]:

Konversi Nilai RGB ke YCrCb (Luminance dan Crominance) menggunakan rumus yang

$$
\begin{aligned}
& \mathbf{Y}=0.257^{\star} R+0.504^{\star} G+0.098^{\star} B+16 \\
& \mathbf{C b}=-0.148^{\star} R-0.291^{\star} G+0.439^{\star} B+128 \\
& \mathbf{C r}=0.439^{\star} R-0.368^{\star} G-0.071^{\star} B+128
\end{aligned}
$$

\section{Contoh Perhitungan:}

$$
\begin{aligned}
\mathbf{Y} & =0.257^{\star} 2+0.504^{\star} 1+0.098^{\star} 3+16 \\
& =0.5+0.5+0.3+16=17.3 \\
\mathbf{C b} & =-0.148^{\star} 2-0.291^{\star} 1+0.439^{\star} 3+128 \\
& =-0.3-0.3+1.3+128=128.7 \\
\mathbf{C r} & =0.439^{\star} 8-0.368^{\star} 1-0.071^{\star} 3+128
\end{aligned}
$$


$=0.9-0.4-0.2+128=128$

\subsection{Tahap Menghitung Nilai ELA}

Tahap berikutnya, setelah proses konversi nilai RGB ke $\mathrm{YCrCb}$ adalah mencari perbadaan nilai rata-rata dari Luminance dan Crominance $(\boldsymbol{\mu})$ yang menghasilkan nilai ELA (Qn) menggunakan rumus yang diambil dari [2] adalah sebagai berikut:

$\boldsymbol{\mu}=\frac{Y+C r+C b}{3}$

$\Delta=|\mathrm{Y}-\mathrm{Cr}| \times(1.0-0.51)+|\mathrm{Y}-\mathrm{Cb}| \times(1.0-0.51)$

Qn $=100-\mu-\Delta$

\section{Contoh Perhitungan:}
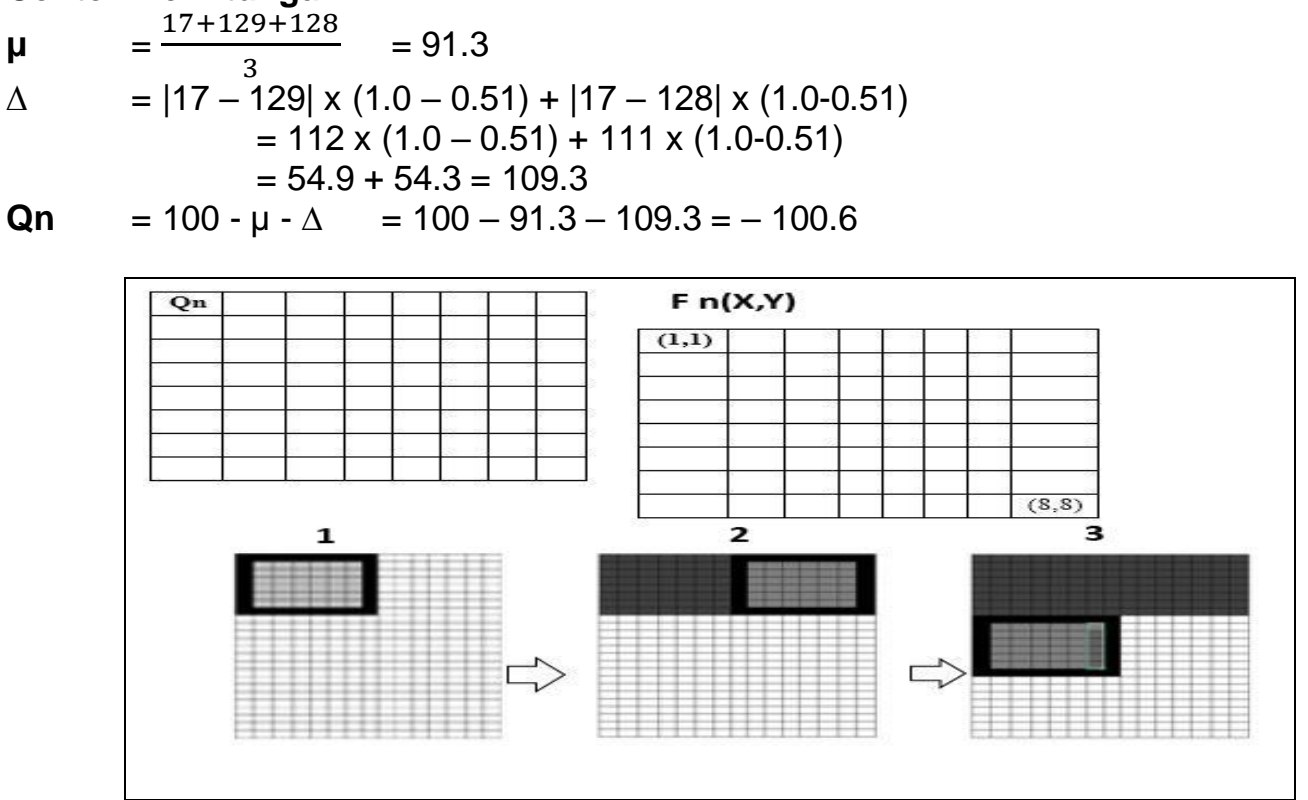

Gambar 2. Gambaran Proses alur perhitungan nilai ELA pada citra

Perhitungan nilai ELA akan terus dilakuakan dari kordinat piksel $(1,1)$ sampai dengan kordinat piksel $(8,8)$ untuk perhitungan pada grid $8 \times 8$ piksel. Perhitungan pada grid $8 \times 8$ piksel akan terus dilakukan hingga panjang atau lebar piksel pada citra kurang dari 8 piksel, sehingga perhitungan pada grid $8 \times 8$ piksel tidak memungkinkan.

\subsection{Tahap Membedakan Nilai ELA}

Tahap membedakan nilai ELA dilakuan setelah perhitungan nilai ELA pada grid $8 \times 8$ piksel. Proses ini juga bekerja pada grid $8 \times 8$ piksel dengan melakukan proses pemilahan nilai yang berbeda. Nilai yang berbeda dari nilai umumnya akan dianggap sebagai nilai ELA dan jika nilai tersebut melewati nilai ambang batas yang ditentukan misalnya nilai yang ditentukan adalah $1 / 4$ dari jumlah blok piksel (64) maka variabel temp akan ditambahkan nilai 1.

\begin{tabular}{|l|l|l|l|l|l|l|l|}
\hline $\mathbf{8 1}$ & $\mathbf{8 1}$ & $\mathbf{8 1}$ & $\mathbf{8 1}$ & $\mathbf{8 1}$ & $\mathbf{8 1}$ & $\mathbf{8 1}$ & $\mathbf{8 1}$ \\
\hline $\mathbf{8 1}$ & $\mathbf{8 1}$ & $\mathbf{8 1}$ & $\mathbf{8 1}$ & $\mathbf{8 1}$ & $\mathbf{8 1}$ & $\mathbf{8 1}$ & $\mathbf{8 1}$ \\
\hline $\mathbf{8 1}$ & $\mathbf{8 1}$ & $\mathbf{8 1}$ & $\mathbf{8 1}$ & $\mathbf{8 1}$ & $\mathbf{8 1}$ & $\mathbf{8 1}$ & $\mathbf{8 1}$ \\
\hline 90 & 90 & 90 & 90 & $\mathbf{8 1}$ & $\mathbf{8 1}$ & $\mathbf{8 1}$ & $\mathbf{8 1}$ \\
\hline 90 & 90 & 90 & 90 & $\mathbf{8 1}$ & $\mathbf{8 1}$ & $\mathbf{8 1}$ & $\mathbf{8 1}$ \\
\hline 90 & 90 & 90 & 90 & $\mathbf{8 1}$ & $\mathbf{8 1}$ & $\mathbf{8 1}$ & $\mathbf{8 1}$ \\
\hline 90 & 90 & 90 & 90 & $\mathbf{8 1}$ & $\mathbf{8 1}$ & $\mathbf{8 1}$ & $\mathbf{8 1}$ \\
\hline 90 & 90 & 90 & 90 & $\mathbf{8 1}$ & $\mathbf{8 1}$ & $\mathbf{8 1}$ & $\mathbf{8 1}$ \\
\hline
\end{tabular}

Gambar 3. Gambaran Nilai ELA per 8x8 Piksel 
Variabel temp merupakan variabel bantu untuk menyimpan hasil perhitung per grid $8 \times 8$ jika grid dinilai memiliki nilai error yang melebihi ambang batas yang ditentukan maka variabel temp akan ditambahkan nilai 1 jika tidak maka penambahan nilai adalah 0 .

\subsection{Tahap Menentukan Persentase Nilai ELA pada Citra}

Kernel $8 \times 8$ yang melakukan proses pehitungan nilai ELA dam pemilahan nilai ELA akan terus melakukan perhitungan pada grid $8 \times 8$ citra. Grid $8 \times 8$ yang dimaksud misalnya pada grid dengan kordinat piksel awal $(1,8)$ sampai dengan kordinat piksel akhir $(8,16)$ dan seterusnya hingga sisa lebar atau tinggi blok piksel kurang sama dengan 7.

Setelah proses kernel $8 \times 8$ berakhir, kemudian melakukan perhitungan variabel temp untuk menentukan berapa banyak blok yang melewati batas yang ditentukan untuk mengambil kesimpulan apakaha citra mengalami modifikasi dengan perhitungan

Persentase nilai modifikasi $=\frac{\sum}{J} \times 100 \%$

Keterangan:

$\Sigma=$ Jumlah nilai yang tersimpan pada variabel temp

$\mathrm{J}=$ Jumlah Perhitungan Kernel Blok $8 \times 8$

\section{Contoh Perhitungan:}

Persentase nilai modifikasi $=\frac{180}{200} x \mathbf{1 0 0} \%=\mathbf{9 0} \%$

\subsection{Tahap Menentukan Kesimpulan hasil analisis}

Kesimpulan analisa citra uji didapatkan setelah perhitungan persentase nilai modifikasi dilakukan, dimana ketika persentase nilai modifikasi berada pada rentan nilai tertentu, maka kesimpulan akan menghasilkan informasi bahwa citra yang dianalisis merupakan citra modifikasi.

\section{$3 \quad$ Kajian Pustaka}

Kajian pustaka memuat materi yang menjadi referensi penelitian ini. Referensi yang dimuat yakni terkait Digital Image Forensic, Modifikasi Citra, JPEG, Discrete Cosine Transform (DCT), dan Error Level Analysis.

\subsection{Digital Image Forensic}

Digital Image Forensic merupakan suatu wilayah baru dalam penelitian yang bertujuan melakukan verifikasi keaslian citra dengan mengambil informasi dari citra tersebut. Tujuan dari adanya forensik citra adalah untuk menemukan, mengidentifikasi atau mencari suatu pemalsuan dari suatu citra. Tujuan lainnya adalah untuk melindungi citra dari suatu kejahatan atau penyalahgunaan pada citra [5].

\subsection{Modifikasi Citra}

Modifikasi citra adalah memanipulasi suatu citra digital untuk menyembunyikan suatu informasi yang berguna atau berarti dari suatu citra. Pendeteksian pemalsuan citra terdiri dari dua cara yaitu aktif dan pasif. Pada pendekatan aktif, metode yang sering terdengar adalah cap air digital (digital watermarking) dan tandatangan (signature). Cap air digital merupakan citra yang dimasukan suatu tanda yang tidak terlihat dimana jika ada perubahan, citra akan rusak. Pada pendeteksian secara pasif atau buta (blind), saat pembuktian tidak memiliki informasi apapun sebelumnya [4].

\subsection{JPEG}

JPEG (Joint Photographic Experts Group) adalah sebuah format citra dengan format lossy (dimana metode untuk mengkompresi data dengan hasil perbedaan data yang tidak terlalu jauh dari data sebelum kompresi), tetapi banyaknya error yang tesimpan tidaklah sama. JPEG (Joint Photographic Experts Group) merupakan standar kompresi digital yang dikembangkan oleh Group Joints Photograpic Experts yang menggunakan kombinasi DCT dan pengkodean Huffman untuk mengkompresi suatu citra digital. Pemampatan JPEG merupakan algoritma pemampatan secara lossy. JPEG bekerja dengan mengubah gambar spasial dan merepresentasikan ke dalam pemetaan frekuensi. Salah satu metode dalam pemampatan JPEG yang dapat digunakan adalah metode DCT (Discrete Cosine Transform), dengan memisahkan antara informasi frekuensi yang rendah dan tinggi dari sebuah gambar [10]. 


\subsection{Discrete Cosine Transform (DCT)}

Discrete cosine transform (DCT) adalah teknik kompresi digital kedalam format JPEG. Pada kompresi JPEG, DCT menerima masukan berupa matriks citra berukuran $8 \times 8$, yang kemudian mengubahnya menjadi matriks frekuensi dengan ukuran sama. Sifat dari DCT adalah mengubah informasi citra yang signifikan dikonsentrasikan hanya kepada beberapa koefisien DCT. Discrete cosine transform adalah sebuah skema lossy compression dimana NxN blok ditransformasikan dari domain spasial ke domain DCT. Discrete Cosine Transform (DCT) adalah sebuah teknik untuk mengubah sinyal kedalam komponen frekuensi dasar [11].

\subsection{Error Level Analysis (ELA)}

Metode Error Level analysis (ELA) adalah sebuah teknik untuk mendekteksi manipulasi citra dengan menyimpan ulang citra pada level kualitas tertentudan kemudian menkomputerisasi perbedaan antara level kompresi. Jika citra tidak diubah, grid $8 \times 8$ piksel seharusnya memiliki potensi error yang sama. Tetapi, jika citra diubah, sebagian dari citra yang telah dimanipulasi akan memiliki potensi error yang lebih tinggi dari bagian citra lainnya. ELA bekerja dengan menyimpan ulang citra untuk mengetahui rata-rata error-nya, pada citra kompresi misalnya pada nilai kompresi 95\%, dan kemudian mengkomputasi perbedaan antara citra [1].

\section{Hasil dan Pembahasan}

4.1 Uji Coba Filter ELA

Proses Uji coba filter ELA pada Aplikasi Pengolahan Citra Pendeteksi Modifikasi Citra Menggunakan Metode Error Level Analysis Berbasis Android dilakukan pada data uji [7] yang dicatat ke dalam Tabel 1.

Tabel 1. Data Uji Coba Fungsi Filter ELA

\begin{tabular}{lcccc}
\hline \multirow{2}{*}{ Tipe Modifikasi } & \multicolumn{2}{c}{ Citra yang Terdeteksi pada Kompresi } & \multirow{2}{*}{ Jumlah Citra Uji } \\
\cline { 2 - 4 } & $50 \%$ & $75 \%$ & $90 \%$ & 40 \\
\hline Tekstur & 21 & 24 & 27 & 50 \\
Background & 19 & 34 & 37 & 80 \\
Objek Besar & 19 & 47 & 63 & 80 \\
Objek Kecil & 3 & 36 & 42 & 250 \\
Jumlah Total & 62 & 141 & 169 & \\
\hline
\end{tabular}

Data Uji coba fungsi filter ELA yang dilakukan diperoleh dari melakukan uji coba terhadap 230 citra uji dari data uji [9], dimana data uji dibagi menjadi 4 jenis modifikasi citra berdasarkan dari tekstur, background, objek besar, dan objek kecil. Kelompok data uji tekstur adalah citra modifikasi yang meiliki pola-pola bentuk objek dan latar belakang citra dasar dengan nilai kontras yang tinggi. Kelompok data uji background adalah citra yang mengalami modifikasi sebagain pada latar belakang citra dengan cara menambahkan atau menghilangkan bagian citra tersebut. Kelompok citra objek besar adalah citra uji yang mengalami modifikasi dengan menambahkan satu atau lebih objek dengan ukuran besar. Kelompok citra objek besar adalah citra uji yang mengalami modifikasi dengan menambahkan satu atau lebih objek dengan ukuran kecil. Uji coba akan dilakukan pada 250 citra uji pada kompresi 50\%, 75\%, dan $90 \%$.

Uji coba pada jenis citra modifikasi tekstur pada Tabel 1 tercatat uji coba pada 20 citra uji dengan kompresi $90 \%$ yang paling efektif dalam melakukan proses filter ELA dimana total citra uji yang dilakukan uji coba sebanyak 250 citra dengan kompresi $90 \%$ menghasilkan citra filter ELA yang terdeteksi sebanyak 155 merupakan kompresi yang paling efektif untuk Filter ELA diantara dua nilai kompresi lainnya.

Keberhasilan Metode Error Level Analysis dalam mendeteksi modifikasi citra menggunakan Aplikasi Pengolahan Citra Pendeteksi Modifikasi Citra Menggunakan Metode Error Level Analysis Berbasis Android berdasarkan hasil uji coba filter ELA yang dilakukan. Hasil uji coba dari 250 citra uji, citra yang dapat berhasil terdeteksi berjumlah 169 citra pada nilai kompresi $90 \%$ atau sekitar $67,7 \%$ dari jumlah citra uji. 


\subsection{Uji Coba Analisis Nilai ELA}

Uji coba analisis nilai ELA dilakukan dengan mengambil 100 data uji dari 250 data uji coba filter ELA sebelumnya dan dengan menambahakan data uji berupa citra autentik atau citra yang tidak dimodifikasi sebanyak 20 citra. Data uji citra autentik yang digunakan digunakan untuk menguji kesalahan dalam perhitungan persentase nilai modifikasi.

Uji coba dilakukan pada 2 nilai threshold pada bagian proses membedakan nilai ELA pada citra uji yaitu 8 dan 16 , nilai threshold 8 piksel digunakan karena hasil keseluruhan dari nilai persentase yang menggunakan threshold 8 memiliki nilai yang besar sehingga lebih mudah untuk menentukan nilai rentan persentase sebagai dasar menentukan citra dimodifikasi oleh aplikasi. .

Tabel 2. Tabel Uji Coba Nilai Threshold 8 pada Proses Analisis Nilai ELA

\begin{tabular}{|c|c|c|c|c|c|c|c|c|c|c|}
\hline \multirow[b]{2}{*}{ Jenis Modifikasi } & \multicolumn{9}{|c|}{ Range Persentase Nilai ELA (\%) } & \multirow{2}{*}{$\underset{\mathrm{h}}{\text { Jumla }}$} \\
\hline & $0 \sim 1$ & $1 \sim 10$ & $\begin{array}{c}10 \sim 2 \\
0\end{array}$ & $\begin{array}{c}20 \sim 3 \\
0\end{array}$ & $\begin{array}{c}30 \sim 5 \\
0\end{array}$ & $\begin{array}{c}50 \sim 6 \\
0\end{array}$ & $\begin{array}{c}60 \sim 7 \\
0\end{array}$ & $\begin{array}{c}70 \sim 8 \\
0\end{array}$ & $80>$ & \\
\hline \multirow{2}{*}{$\begin{array}{l}\text { Background } \\
\text { Objek Besar }\end{array}$} & 0 & 9 & 8 & 3 & 0 & 0 & 0 & 0 & 0 & 20 \\
\hline & 0 & 9 & 7 & 2 & 2 & 0 & 0 & 0 & 0 & 20 \\
\hline Objek Kecil & 0 & 14 & 3 & 2 & 1 & 0 & 0 & 0 & 0 & 20 \\
\hline Tekstur & 0 & 0 & 1 & 5 & 7 & 4 & 1 & 2 & 0 & 20 \\
\hline Tak Terdeteksi & 0 & 4 & 3 & 7 & 0 & 6 & 0 & 0 & 0 & 20 \\
\hline Autentik & 13 & 3 & 2 & 1 & 1 & 0 & 0 & 0 & 0 & 20 \\
\hline Total & 14 & 39 & 23 & 20 & 11 & 10 & 1 & 2 & 0 & 120 \\
\hline
\end{tabular}

Uji coba analisis nilai ELA yang tercatat pada Tabel 2 dilakukan dengan nilai threshold 8 pada tahapan perhitungan nilai ELA pada grid 8x8 pixel, dengan menggunakan 120 data uji yang sebelumnya digunakan pada uji coba filter ELA yang dibagi ke dalam 6 kategori citra uji yaitu modifikasi background (BG), objek besar (OB), objek kecil (OK), tekstur (TXT) yang merupakan kategori pada uji coba filter ELA pada sub bab 4.1 uji coba filter ELA, dan tambahan 2 kategori citra tidak terdeteksi (TT) untuk citra uji yang tidak dapat dideteksi pada uji coba filter ELA sebelumnya dan autentik (AU) untuk citra uji yang tidak dimodifikasi. Citra autentik (AU) yang ditambahkan dalam uji coba digunakan untuk melakukan uji coba terhadap kesalahan pendeteksian nilai persentase modifikasi yang mungkin terjadi dalam uji coba analisis nilai ELA.

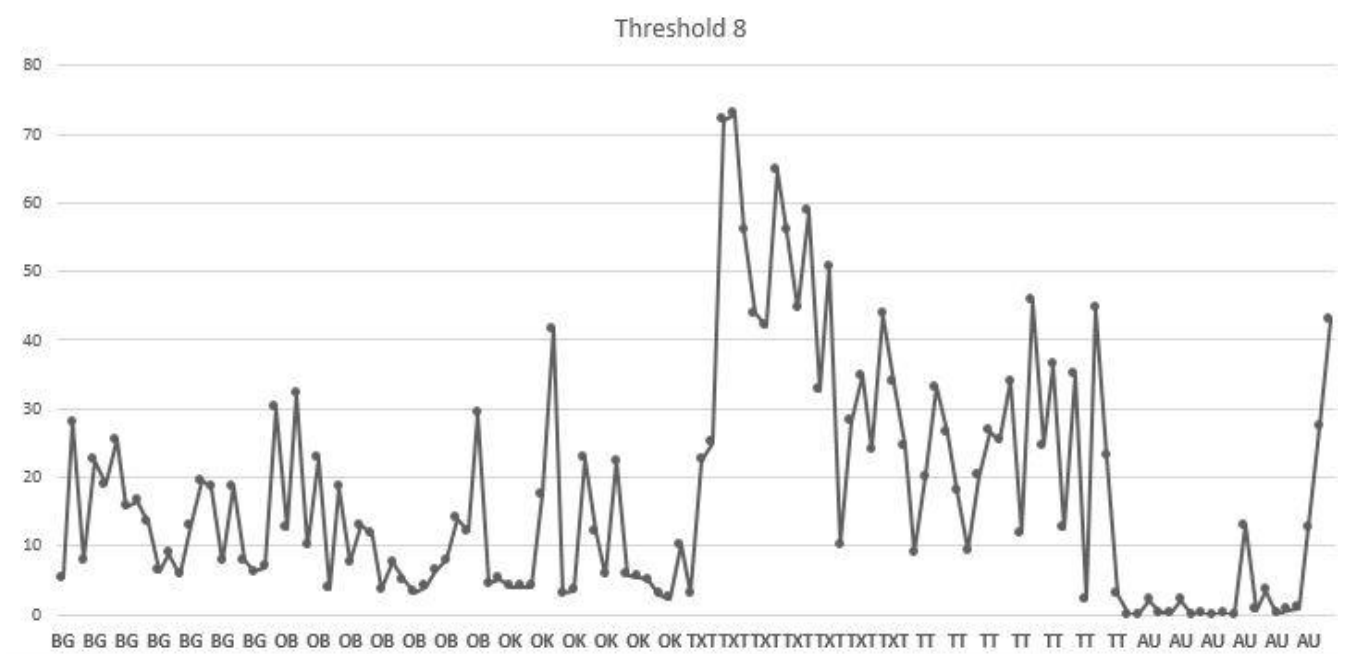

Gambar 4. Diagram Persentase Uji coba Analisis Nilai ELA

Gambar 4 adalah grafik dari nilai persentase ELA pada uji coba menggunakan nilai threshold 8 mengacu pada data Tabel 2 menujukan nilai persentase untuk jenis modifikasi tekstur (TXT) memiliki rata-rata persentase nilai ELA terbesar yaitu 42,05 persen, dengan nilai persentase terbesar adalah 72,98 persen. Uji coba dapat mendeteksi semua citra uji (TT) dengan 
rata-rata nilai persentase ELA 23,06 persen, dengan nilai persentase terbesar pada nilai 45,7 persen, hasil ini membuktikan bahwa analisis nilai ELA berhasil mendeteksi citra uji modifikasi yang tidak dapat ditedetksi secara kasat mata melalui filter ELA. Citra uji Autentik (AU) yang digunakan sebagai perbandingan untuk menentukan rentan persentase nilai ELA memiliki ratarata nilai kemuculan sebesar 7 citra uji dari 20 citra uji, yaitu sebesar 35 persen, dengan nilai ratarata persentase nilai ELA adalah 14,7 persen. Perbandingan nilai kesalahan dilakukan dengan membandingan jumlah citra uji autentik yang terdeteksi pada nilai range yang sama dengan jumlah citra uji yang terdeteksi pada range tersebut dikalikan 100 persen yaitu sama dengan rumus peluang keluarnya citra autentik selama uji coba.

\section{Kesimpulan}

Aplikasi Pengolahan Citra Pendeteksi Modifikasi Citra Menggunakan Metode Error Level Analysis Berbasis Android yang dibangun memiliki dua fungsi utama yaitu filter ELA dan analisis nilai ELA sebagai alat untuk melakukan uji coba terhadap Metode Error Level Analysis, hasil uji coba filter ELA dipengaruhi oleh faktor kontras dan kecerahan warna yang digunkan dalam modifikasi citra berdasarkan hasil uji coba filter ELA yang dilakukan. Metode Error Level Analysis berdasarkan uji coba filter ELA memiliki toleransi dalam mendeteksi citra yang dimodifikasi dari 2 atau lebih dengan syarat citra yang memiliki nilai kontras dan kecerahan warna yang tinggi. Keberhasilan Metode Error Level Analysis dalam mendeteksi modifikasi citra menggunakan Aplikasi yang dibuat, berdasarkan hasil uji coba filter ELA yang dilakukan adalah dari 250 citra uji, citra yang dapat berhasil terdeteksi berjumlah 169 citra pada nilai kompresi $90 \%$ atau sekitar $6,76 \%$ dari jumlah citra uji dengan catatan toleransi metode dalam mendeteksi citra modifikasi. Analisis nilai ELA yang dilakukan sudah berhasil mendeteksi citra modifikasi yang tidak dapat dideteksi pada uji coba filter ELA. Rentan persentase nilai ELA yang diacatat dalam mendeteksi citra uji yang telah dimodifikasi adalah 2,27 hingga 72,98 persen untuk penggunan nilai threshold 8 , dengan dengan nilai kemukinan kesalahan sebesar 35 persen berdasarkan uji coba yang dilakukan.

\section{Daftar Pustaka}

[1] Wijaya, A. Y., Musayyab, S. Al, \& Studiawan, H. (2017). Pengembangan metode block matching untuk deteksi copy-move pada pemalsuan citra. Jurnal Ilmiah Teknologi Informasi, 15(1), 84-94.

[2] Gunawan, T. S., Hanafiah, S. A. M., Kartiwi, M., Ismail, N., Za'bah, N. F., \& Nordin, A. N. (2017). Development of photo forensics algorithm by detecting photoshop manipulation using error level analysis. Indonesian Journal of Electrical Engineering and Computer Science, 7(1), 131-137. https://doi.org/10.11591/ijeecs.v7.i1.pp131-137

[3] Zulfan, F. A., dan Rusdha Muhara (2016). "Deteksi Pemalsuan Citra dengan Teknik CopyMove Menggunakan Metode Measure dan Koefisien Menggunakan Metode Ordinal Measure dari Koefisien Discrete Cosine Transform." 5

[4] Li, B., Ng, T. T., Li, X., Tan, S., \& Huang, J. (2015). Revealing the trace of high-quality JPEG compression through quantization noise analysis. IEEE Transactions on Information Forensics and Security, 10(3), 558-573. https://doi.org/10.1109/TIFS.2015.2389148

[5] Widiakumara, I. K. S., Putra, I. K. G. D., \& Wibawa, K. S. (2017). Aplikasi Identifikasi Wajah Berbasis Android. Lontar Komputer, 8(3), 200-207.

[6] Andika, I. P. P., Bayupati, I. P. A., \& Kadek, N. A. W. (2015). Rancang Bangun Aplikasi Pendeteksi Tipe Dan Nilai Resistor Berbasis Android. Jurnal IImiah Teknologi Informasi, $6(1), 61-72$.

[7] http://forensics.idealtest.org/casiav2/, diakses pada 1 Maret 2018)

[8] Adiyat, I. (2013). Aplikasi Pengolah Citra Digital Berbasis Flash pada Perangkat Mobile lqbal Adiyat Building for iOS, 3-6.

[9] Utomo, A. P., Putra, A. E., \& Atmaji, C. (2012). Analisis Hasil Proses Pemampatan JPEG dengan Metode Discrete Cosine Transform. IJEIS (Indonesian Journal of Electronics and Instrumentation Systems), 2(1), 1-10. https://doi.org/10.22146/ijeis.2335

[10] Tearani, N. P. (2014). Peningkatan Kompresi Citra Digital Menggunakan Discrete Cosine Transform - 2 Dimension ( DCT - 2D ), 1-5. Retrieved from http://eprints.dinus.ac.id/id/eprint/13174 